\title{
Gender analysis of livelihood strategies among ethnic households in Northern Laos: From subsistence agriculture to rubber plantations
}

Kyoko Kusakabe and Chanthavisith Chanthoumphone

Rubber plantations, promoted by the governments of Cambodia, Myanmar and Laos, have reduced people's access to forests. As a result, villagers have to buy food from markets, forcing women to look for higher cash incomes, which is more time-consuming (Julia and White 2013). Whitehead and Kabeer (2001) noted that small landholders use diversification as a strategy for survival or for accumulation, but women often pursue livelihood strategies that are less lucrative than those adopted by men (Agarwal 2003, Kandiyoti 2003). Despite earning a lower income than men, women continue to bear the responsibility of feeding the family, and hence have to manage food security and nutritional deprivation (Schneider 2011). Feminist political ecology scholars have examined such gender-differentiated impacts, from an intersectionality perspective, taking into account other subjectivities like ethnicity and age (Elmhirst et al. 2017; Elmhirst 2011; Nightingale 2011). They examine how changes in the material environment create normative gender roles (Sultana 2009) and highlight the importance of the gendered nature of everyday experiences (Terry 2011). An approach that explores everyday experiences helps us understand locational and contextual diversities in gender outcomes (Arun 2012; Angeles and Hill 2009; Hall et al. 2017).

Research into the impact of rubber plantations has revealed both positive and negative impacts. Khamphone and Sato (2011) maintained that the impact is positive for smallholder rubber producers, while negative impact is usually noted among farmers who undertake contract farming and are employed in investors' rubber plantations. Despite the numerous studies conducted on the impact of rubber plantations in northern Lao PDR (Thongmanivong et al. 2009; Dwyer 2013,2014; Shi 2008; Friis et al. 2016; Lindeborg 2012; Lagerqvist 2013; Sturgeon 2012; McAllister 2015; Kenny-Lazar et al. 2018), gender analysis is limited (Park and Daley 2015 is an exception).

Highlighting diversity does not mean that we simply demonstrate variations under different circumstances. It is important to highlight the factors and subjectivities that create 
disparities. Analysing diversities gives us a nuanced understanding of the disadvantages that poor women and other marginalised people experience. We study the impact of rubber plantations in different socio-cultural contexts. Factors such as location (distance from the border), infrastructure (distance from roads), land regulations (concession, collaboration, small farm holdings) and timeline (early, middle and late adopters) are included to offer a more nuanced perspective on the differential impact on women and men in terms of their livelihood, income, workload and power relations.

Following Turner et al. (2015), this analysis of livelihoods focuses on locational contexts. Turner et al. (2015) critiqued the livelihood approach for its focus on material access and capital and 'disregard [for] local particularities' (p.6) in their study of the Hmong community at the Vietnam border. They argued that the particular situation created by the borderland shaped the responses of individuals and households such that it was unique and 'not fully coherent with the market economy' (p.11). They call this 'everyday covert resistance' (p.11). The effect of borders on the way people make livelihood decisions has been identified by different scholars (Sturgeon 2005; Horstmann and Wadley 2006). Borderlands create a special space where State control can be diluted because of the distance from the centre. What Long (2001:65) calls 'social interface', where different values and conflicts meet and negotiate, is often seen in borderlands. This paper approaches the diversity in the coping strategies employed by women and men in terms of space and border and the social interface they create.

The paper is structured as follows: the next section provides the history of rubber plantations in northern Lao PDR. The study site is categorised by location and the timing of the introduction of rubber production. An analysis of the changes in gender-based division of labour is followed by an analysis of women's decision-making power and investments for women. Following the gender analysis, we conclude with a discussion on how the previously discussed location and timing shape people's coping strategies and its implications within the wider context of the sustainability of local livelihoods.

\section{Rubber plantations in northern Lao PDR}


Luang Namtha is home to various ethnic groups with differing exposure to the outside economy and rubber production. The area has a history of forced resettlement and the struggle to control forest land continues (Evrard and Goudineau 2004; Kusakabe and Vongphakdy 2014).

Rubber was introduced in Luang Namtha in the early 1990s. Hmong villagers in Hadyao learned about rubber from the Hmong network in China. They then purchased and planted rubber. With Hadyao as a pilot, the government, from 1994, began promoting rubber as a crop to supplement farmers' income. However, since villagers were slow to adopt the practice, the government started awarding land concessions to Chinese companies for the quick expansion of rubber plantations.

Luang Namtha saw large investments in rubber plantations after a Memorandum of Understanding (MoU) was signed between the governments of China and Laos in 1997 to enhance trade. The Chinese government promoted rubber as an alternative to opium under its alternative crops project (Shi 2008). Cross-border investment in rubber began increasing around 2002 and reached around 33,000 hectares (ha) in 2016 (Buaphan Namnavong, Department of Agriculture and Forestry, presentation on 31 October 2016). In Luang Namtha, 33 investment projects were approved by 2016, of which 22 were for rubber. The province now has six rubber-processing factories.

Simultaneously, villagers started developing rubber plantations themselves. For example, one Hmong village tapped its ethnic network to learn how to grow rubber from Hadyao villagers and started planting on their own (see also Kusakabe et al. 2015; Lindeborg 2012). As the global rubber price increased, so did investments. The rubber boom reached its peak between 2008 and 2011. Concerned about the uncontrolled expansion of rubber plantations through land concessions and the drop in rubber prices (Lu 2015), the Prime Minister's Order No. 13 (PM13), issued in June 2012, declared a moratorium on new concessions for rubber (and for mines and eucalyptus plantations) until the end of 2015, which was later extended for another year. 
The provincial government offered guidelines on various land arrangements between companies and villagers. Classifying land arrangements into $1+4$ (land given by villagers and managed by companies) and $2+3$ (land and labour provided by villagers), the government encouraged the latter. In Luang Namtha, many villages followed the 1+4 system, and after planting, a portion of the land with rubber trees was returned to villagers. Companies hired villagers on daily wages to work on their lands. In some villages near town, urban dwellers rented land and planted rubber. Landowners were often hired to take care of the rubber, thus earning both land rental and daily wages.

There are different views on the impact of rubber plantations in northern Laos. Friis et al. (2016), in their study in Luang Prabang province, noted a negative impact. Chinese rubber plantations had changed land-management systems and denied farmers access to their upland fields. Rubber plantations made it impossible to raise cattle, which lowered paddy yields, because of the lack of manure. People with fewer resources in the village were affected since they could not access land, leading to increased outmigration and disparity among villagers.

On the other hand, Lagerqvist (2013), in her study in Sing District of Luang Namtha province, portrayed how farmers used rubber plantations to legitimise their claims to land at the borders. Villagers utilised the capital from their cross-border connection to invest in rubber and lay claim to land before it was taken over by larger external investors. Rubber planting thus helped secure their land and livelihoods. However, she also noted that not everyone could negotiate with the company and State in this way. Some people are dependent only on meagre wage work, rather than subsistence upland farming, thus increasing their vulnerability.

The differences in location (border vs non-border area) was a key factor between the two studies. Farmers in both studies needed to secure their land, but the border villages had the advantage of mobilising information and connections in China to lay claim to land through their own rubber production. In Luang Prabang, however, such knowledge mobilisation was more difficult. By exercising agency, local farmers are adapting to the market economy. The impact of rubber plantations is thus complex and context specific. 


\section{Methodology}

The paper draws from field research conducted in Luang Namtha province, Lao PDR. Eight villages in the province were selected for the study: ${ }^{1}$ two (village $A$ and B) in Luang Namtha district, three in Vieng Phouka district (village C, D, E) and three in Sing district (village F, G, H). Three are Akha villages, two Khmu villages, one Hmong village, one Leu village and one mixed village (Lao Huai, Pu Noi, Hmong). The villages were purposively selected to cover various ways rubber was introduced in the area. In one village, farmers planted rubber themselves. Four villages entered into contract farming arrangements with a company (they received seedlings and will sell rubber to the company or the company gets land from the village and villagers get a share of the rubber harvested; the exact form and share of economic benefit varies widely). And three villages are under full concession (a company totally controls the land and operation of the rubber plantation).

Since most rubber planting, both by farmers and through concessions, started in 20062007, many plantations were able to start tapping in 2013-14. However, because of the drop in global rubber prices, companies are not tapping rubber now. Some farmers cut down rubber trees and planted banana or watermelon. The transition to rubber has been a challenge for many farmers, mainly because of (i) the gap of seven years before rubber yields an income, and (ii) the lack of labour in the area.

Of the 530 households in the study villages, a questionnaire survey was conducted with 225 men and 137 women from different households. Questionnaires were used to get basic information on livelihood changes before, during and after rubber plantation. We wanted to interview as many women as possible and an equal number of men, but it was difficult to get women respondents. This was because many women did not speak Lao language or because they wanted us to talk to their husbands instead. Follow-up interviews were conducted with 30 men and 31 women and two focus group discussions (FGDs) were held

\footnotetext{
${ }^{1}$ Villages and respondents are being kept anonymous.
} 
with women's groups to capture how they felt about the changes. Interviews were conducted between December 2014 and December 2015.

\section{The villages studied}

The eight villages studied are classified into four clusters according to the location (border/road), timeline of planting rubber (early, middle or late adopter), and land arrangement (own plantation or concession).

Cluster 1: Villages bordering China where small rubber plantations started in the early 2000s

Cluster 2: Villages where rubber was planted without company intervention in the mid2000 s

Cluster 3: $\quad$ Roadside villages where rubber planting started on a 1+4 arrangement with companies in the mid-2000s

Cluster 4: $\quad$ Remote villages where rubber planting started in the late 2000s and dependence on wage work in rubber plantations is high

\begin{tabular}{|c|c|}
\hline Cluster 1 & Cluster 2 \\
\hline Near Chinese border & Near Burmese border \\
\hline Easy access to roads & No access to roads \\
\hline Early adopter & Middle adopter \\
\hline Own plantation & Own plantation \\
\hline Cluster 4 & Cluster 3 \\
\hline Remote & Non-border \\
\hline No access to roads & Easy access to roads \\
\hline Late adopter & Middle adopter \\
\hline Company plantation & Company plantation \\
\hline
\end{tabular}

Cluster 1: Villages bordering China where small rubber plantations started in the early 2000s 
The two villages studied in Sing district (villages $F$ and $G$ ) are both Akha, located just across the border from China and in frequent communication with people on the other side of the border. They had planted sugarcane under a contract farming arrangement with Chinese merchants and quit when prices fell. Then, they learned about rubber from relatives in China and started planting in the early 2000s. They started harvesting when rubber prices were rather high and benefited as a result. Their location and their ability to go to China as wage labourers also proved beneficial. Wages in China were higher than in Laos, but these have recently evened out, so the movement to China for work has decreased. Agricultural wage, in general, has increased after rubber plantations were introduced, because of the shortage of labour. Before rubber plantations, daily wage was only 20 yuan per day; now, it is 50 yuan.

From 2010, Chinese merchants started renting villagers' paddy fields to cultivate banana. Many families in these villages have rented out their paddy land to the Chinese and some women work on these banana plantations as wage workers.

The villagers continue marginal upland rice production, but they now depend more on cash income to feed their families. On average, their cash income sources are: rubber (50\%), land rental (30\%), wage labour ( $20 \%$ for village $F$ and $5 \%$ for village $G$ ) and livestock ( $10 \%$ for village $\mathrm{G}$ ). Villages $\mathrm{G}$ and $\mathrm{F}$ have the highest cash income among all those studied, at 3 million kip (360 USD) and 1.5 million kip (180 USD) per month, respectively. This is double the income in Cluster 3 and 4-8 times higher than the income in Cluster 4.

Before rubber, their income came from various sources: wage work, Non-Timber Forest Product (NTFP) collection, livestock and sale of paddy and upland rice. A few people earned considerable income from sugarcane production. Their proximity to China meant that they planted cash crops and rubber much earlier than others in Laos, making them economically better off than other villages. As Sturgeon et al. (2013) noted, the Akhas on the border with China have successfully adopted commercial agriculture without government assistance. 
Cluster 2: Villages where rubber was planted without company intervention in the mid$\underline{2000 s}$

In the two villages in this category (Village $\mathrm{H}$ and Village $\mathrm{A}$ ), farmers planted rubber on their own. Village $H$ is a Leu village that borders Myanmar. It is difficult to access by road. In 1998, GTZ built a road to connect the village to the highway, but this is impassable during the rainy season. It is easier to access the Chinese market by boat. Mobile phones were introduced in 2008 through a Chinese network. Because of the village's location, subsistence livelihood was the norm, and $90 \%$ of cash income came from selling livestock.

The villagers in village $\mathrm{H}$ planted rubber in 2000 . A rubber concession was started nearby in 2007, but it became inactive after an accidental forest fire destroyed parts of it. More rubber plantations (around $13 \mathrm{ha}$ ) are owned by individual small holders than by this concession (around 10 ha, of which 1 ha burnt down). At present, the village's cash income sources are: rubber (55\%), wage labour (mainly from concessions, $20 \%$ ) and livestock (25\%). They also undertake paddy production for home consumption. Their remote location gives them access to forests and NTFP. They transport rubber to China by boat and get a slightly better price than inland farmers.

Village A has a mix of Lenten, Pu Noi and Hmong and is located in Luang Namtha district. It lies along a small road. No company has ventured a rubber plantation in Village A. Before rubber, the villagers earned cash income from upland rice (25\%), NTFP (25\%) and wage work $(50 \%)$. The village is near a protected national forest and has its own forest as well, so most people have no trouble collecting NTFP. However, taking advantage of the road, they have also taken up wage labour and contract farming of corn and mak naman (oil tree or sacha inchi). Ever since the rubber plantations reached maturity, the sale of rubber has contributed to $40 \%$ of the village's cash income; $50 \%$ comes from wage labour. Their location along the road gives them access to the market, and their cash income has improved. This additional cash income is being used for better nutrition. They also market their rubber collectively and get a slightly better price. 
Cluster 3: $\quad$ Roadside villages where rubber planting started with 1+4 arrangement with companies in mid-2000s

Two Khmu villages (Village $\mathrm{E}$ and $\mathrm{D}$ ) and one Hmong village (Village $\mathrm{C}$ ) were studied in this cluster. These are located along the main road and were thus involved in the market economy even before rubber was introduced. Before rubber, their cash income sources were diverse. They used seedlings provided by companies to start planting rubber. Their cash income from rubber is not large, and they maintain diverse cash income sources.

Village $\mathrm{E}$ is a Khmu village established in 1997. It saw several development projects as well as a land-distribution project that provided each household a vegetable field. Villagers started planting rubber in 2005 , when a Chinese company came to set up a rubber plantation. In exchange for land, the company gave 144 seedlings to each household: a $1+4$ arrangement. Before rubber plantation, the villagers earned cash from paddy (10\%), livestock (45\%), corn (10\%), wage labour (15\%) and NTFP (10\%). ${ }^{2}$ Now, their income sources are rubber (15\%), livestock (55\%) and wage labour (5\%). Their cash income has increased substantially in real terms. However, economic improvement came from corn and rice, not rubber.

Village $D$ is also a Khmu village and has had several poverty-alleviation projects. It started cultivating rubber in 2005-6 when a Chinese company gave each household 300 seedlings in exchange for village land: a 1+4 arrangement. None of the respondents had their land taken away by the concession. Their cash income before rubber came from paddy (15\%), upland rice (20\%), NTFP (25\%) and wage work (30\%). Now, it comes from paddy (15\%), rubber (30\%), wage work (25\%), NTFP (10\%) and upland rice (5\%).

Village C, a Hmong village, started planting rubber in 2004, when a company came. The villagers used to plant opium, but after the 2003 ban, they switched to corn. Before rubber, they used to earn cash income from paddy (20\%), NTFP (40\%), corn (10\%) and wage work

\footnotetext{
2 Since this is an aggregate of the respondents in this village, percentages do not necessarily add up to $100 \%$. It also excludes various other small income sources.
} 
(15\%). Now, this has changed to cash crops like sugarcane (30\%), paddy (10\%), rubber (10\%), wage work (20\%) and livestock (20\%). It has become increasingly difficult to raise livestock because of increasing rubber plantations, so the income from livestock is actually from the distress sale of cattle and is unsustainable.

Individual farmers have negotiated different arrangements with the company. Some bought seedlings from the company, others took seedlings with a promise to pay later and some got seedlings in exchange for a promise of mature rubber trees. However, so far, the company has not returned to collect the money or trees. They did not have a written contract, and it is not clear whether the company has been deterred by low rubber prices or the farmers misunderstood the contract and are supposed to give up a share of the harvest.

Cluster 4: $\quad$ Remote villages where rubber planting started in late 2000s and dependence on wage work in rubber plantations is high

Unlike in the above three clusters, where rubber producers with small holdings dominate (although they do undertake wage labour in the rubber concessions from time to time), villagers in this cluster are wage labourers at rubber concessions. Village B is an Akha village relocated in 2006. Since it was relocated, Village B does not have any paddy land. The villagers started rubber in 2008 after a company gave them some trees. Before rubber, almost all its cash income came from NTFP. It also had the largest upland cultivation area among all the villages studied. These upland fields were taken over by the rubber company and have since shrunk by $30 \%$. Plots of rubber were provided as compensation, but the trees did not grow well and have not been harvested. Currently, Village B's cash income comes from NTFP collection (55\%) and wage labour (30\%), both of which are undertaken by women.

Each household received 300 rubber trees from the company, although the amount of upland lost was not equal. Some households lost 2 of the 3 ha they were cultivating, while some lost only 0.5 ha. The relocation and rubber concessions have affected their livelihood, especially those of the women. 
If we do not have enough to eat, women will eat less. (Mr. YH, 30 years old)

\section{Effect of livelihood change on gender division of labour}

Once the villages started harvesting rubber, women's workload decreased while that of men increased. This was due to the decrease in NTFP collection and upland rice production and increased reliance on income from rubber production. For example, in Cluster 1, before rubber was planted, men grew paddy while women undertook upland rice cultivation, NTFP collection and, usually, more wage work than men. Women would go in groups to China for wage work. A similar division of labour existed in Cluster 2 and 3.

Women's workload was high because they were responsible for family subsistence. As Sturgeon (2005) mentioned in her study of Akha in China at the Lao border, when faced with food shortage on State-allocated land, women undertook swidden to feed the family. Women defy existing rules to cope with change, which Sturgeon called their 'plasticity'.

\section{[TABLE 1 HERE]}

Rubber became more of a man's crop (Table 1) because it was introduced by outsiders and through the government, groups that women rarely interacted with. It yielded a relatively large cash income, especially during the rubber boom, thus attracting greater interest from men. It required an initial investment, and such decisions were largely (more than $90 \%$ according to respondents) made by men. At the same time, rubber did not yield an immediate income and often could be harvested only after seven years. Women, who are responsible for food security, took up a secondary role in rubber management and supported their families by intercropping rice and corn in rubber fields and through wage work and NTFP collection.

As seen in Table 1, more men in Cluster 1 and 2 say they are busier than women after rubber was planted. These clusters have benefited the most from rubber, since the 
plantations were started earlier. It was not only the introduction of rubber, but also technology that changed the gender division of labour. Earlier, weeding was done by women. With the introduction of herbicide, this work has shifted to men. With the introduction of motorbikes, farmers now ride to their fields, and women refuse to go to the field if the men do not take them. Hence, men go to the fields more often than before.

When we ride the motorbike to the field, both women and men have to go together. If men do not go, women refuse as well, so men have to accompany women to the field. (FGD with women in Village G, Cluster 1)

However, women still find that they work more than men.

Both women and men are busier than before. Husbands are taking up more work, but women still work more than men. (Ms. NY, 38 years old in Cluster 3)

The intensity of work has also increased.

Earlier, we suffered more, since we did not have much income. Now, it is busier, because one needs to go and tap rubber every day, and we cannot rest. For hai (upland field), if we did not feel like going, we could skip a day. We cannot do that with rubber. We need to wake up early in the morning, which is tiring. Work is not heavy, but it is tiring. But it is OK, since we have more money. (Ms PM, 30 years old in Cluster 1)

In Cluster 4, the division of labour has not changed and women continue to collect NTFP and engage in wage work. The rubber concession nearby provides women wage work. Men's work did not increase because they did not take up rubber production themselves.

Investments for women and women's decision-making powers 
A World Bank report (2017) pointed out that among ethnic minorities, dropout rates were higher for girls. Schenk-Sandbergen (2012) described how most ethnic groups except TaiKadai such as Leu and Phu-Thai follow more patri-social kinship patterns. Many ethnic groups included in this study, such as Akha, Hmong, Khmu and Lenten, are patrilocal, that is 'male dominance through the ownership of the means of production, patrilocal residence patterns and patrilinear descent, and inheritance patterns.... Women of these group have less access to economic resources but have to do almost all the production and household labor' (Schenk-Sandbergen 2012:76). Lyttleton et al. (2004) maintained that young Akha men controlled women's sexuality and served as gatekeepers for outsiders to access their women and cultural norms did not allow women to object.

The villages studied are all patriarchal but to different degrees. Land inheritance is through men, who are also heads of households and the main decision makers. However, even in the most patriarchal Akha villages, as in Cluster 1 and 4, land can be inherited by women. In Village $F$, in Cluster 1, half of the respondents with inherited land said they had got it from their wife's parents. In Village G, in Cluster 1, the proportion of such inheritance was lower but still existed. As Schenk-Sandbergen (2012) pointed out, categorising ethnic groups by their patrilineal/matrilineal practices is getting more complex with resettlement policies, better roads and greater exposure to mainstream lowland Lao practices. However, in all communities, women's position remains lower than that of men.

The increase in cash income from rubber and greater exposure to outsiders as a result of being involved in markets have brought about some changes in the position of women in the community. In Cluster 1, exposure to outsiders has changed the way villagers eat at home. The head of Village $G$ and his wife eat together with guests, which is not normal practice in Akha households. They said that they had heard from the Women's Union that it was better to eat together. Unlike other Akha villages in the province, women here are more comfortable interacting with outsiders.

Although household decision-making is still dominated by men, women's voices are gaining strength in decisions regarding the purchase of household goods. Villagers in Cluster 1 
started buying refrigerators on the request of women, since it reduces their work in preparing food.

I wanted to have a refrigerator, so my husband took me to the market to buy one. (Ms. YP, 36 years old in Cluster 1 )

Women are also asserting greater control over household finances.

Earlier, men used to keep the money. Now, we earn more, but we cannot keep it with men, since they would spend it all on drink. So, women keep the money, but if our husbands ask, we have to hand it over. We need to agree on what to buy together. (FGD in Village G, Cluster 1)

Women also have more say in household decision-making. Since they have more money, women can buy what they want.

If we want to eat something, we can go and buy it. We can go to the market as often as we want. Now, when we are sick, we can go to the health centre. Earlier, even if we wanted to go to the hospital, we could not. It was too far to walk and too expensive to hire a car. (Ms. AM, 36 years old in Cluster 1 )

Villages invested in rice mills and water supply, at both the household and the community level, thus drastically reducing women's workload. In Cluster 1 , increased income has spurred villagers to invest in improving the village water supply and electricity. Households contributed to collectively construct a water supply system that ensures that all homes have running water. The village decided to use the money paid by Chinese companies for rubber concessions to get electricity to the village. This has greatly reduced women's workload.

Now, it is easier to cook, because there is electricity and running water at home. So, we can cook faster. Earlier, water was far away and had to be carried home. (FGD in Village G, Cluster 1 ) 
In Cluster 3, 47\% in Village D, 19\% in Village $E$ and $71 \%$ in Village $C$ said that they now buy cooked food from the market. This is because women have become far busier with rubber and other cash-income generating occupations and do not have time to cook. Market proximity also makes it easier to buy cooked food.

After rubber production, we have become much busier. Much, much busier. There is no one in the village anymore. You can see that all doors are shut. (Head of Village $E$, Cluster 3)

The change in livelihood has led to older people staying in the village; thus, older women are available to care for grandchildren.

Now, it is easier to leave the child in the village, since older women stay at home. Earlier, older women also went to the hai, but they do not work on the rubber plantation and stay at home longer. So, it is easier to find someone to look after the children. (FGD women, Village E, Cluster 3)

Earlier, when women had to stay at the upland fields during farming period, and spent extended time in the forest collecting NTFP. But with changes in livelihood, women now have more time to stay in the village and interact with outsiders. The decrease in upland farming and NTFP collection leaves women with more free time, part of which is used to go to the market. Most women respondents said their trips to the market had increased. In some villages, women's interactions with outsiders is greater than that of men, since the latter are now out in the field or on wage work, and women are in the village.

In Cluster 3, women now attend village meetings more frequently.

Our village is more well-known, so there is more cooperation among the villagers. We have more money and we do not have to always worry about food, so we can spare more time for festivals and community activities. During festivals, people come from outside, so we are busier. (FGD women, Village $\mathrm{E}$, Cluster 3) 
Because women spend more time in the village, they are better informed about what is going on, and hence more active in household decision-making. For example, in Cluster 1, women were aware of the rents that Chinese companies were paying to convert paddy to banana and offered opinions on the decision to rent and the amount to charge. Ms. MP, for instance, is conversant with current rents.

I now regret that I rented out my paddy land. The rent is too low. (Ms. MP, 28 years old in Cluster 1 )

Cluster 1 women said that they now take a greater part in decision making, but Cluster 3 women said that they have always had some say at home.

When planning what to plant, women and men decide together. Since most of the work will be done by women, sometimes, women can say that they do not want to plant this or that. (FGD women, Village E, Cluster 3)

However, some things have not changed. For example, education is still prioritised for sons (Table 1). Only the Leu village (Village $\mathrm{H}$, Cluster 2) has given more priority to daughters' education.

Only in Cluster 4 have gender roles and relations remained unchanged. Akha men still have greater decision-making power than women in the household.

Women do not understand anything. They do not even know how to ride a motorbike. (Mr. AK when asked if his wife had a say in his decision to buy a motorbike, Cluster 4)

Although villagers in Cluster 4 have increased their investment in children's education, it is more for sons rather than daughters. 
Let the boy study, because girls will get married after they turn 10 or so.

(Mr. SP, 24 years old in Cluster 4)

Livelihoods and cash income in Cluster 4 also remain largely unchanged. In a sense, their income has actually decreased because of relocation. Hence, this cluster showed very different patterns from the others.

\section{Questions on sustainability}

Women and men in most of these clusters are pinning their hopes on rubber and we have seen some positive changes, but is this a sustainable livelihood option? Since the completion of our fieldwork, the price of rubber has dropped further and the sustainability of rubber production remains doubtful (Kenney-Lazar et al. 2018). Despite the reduction in unpaid household work for women and their increasing influence in decisions in the household and community, some of these decisions are leading to new problems.

In 2010, Cluster 1 villages started renting out their land to Chinese companies for banana plantations. Women and men were involved in the decision. Women favoured this choice, since it saved them labour. From their perspective, the largest constraint in production was a lack of labour. They considered earning rent on their land easier than planting paddy. However, banana plantations make heavy use of chemicals which might make it impossible for villagers to return to paddy. Some villagers experienced these negative effects when they rented their land to grow watermelon.

I rented out my paddy land to a Chinese company to plant watermelons. But after that, when I planted rice, although it grew well, the seeds were empty. They put too much fertilizer and the soil became too fertile. If we put chemicals, then the soil cannot be used after three years. If we just plant naturally, we can use the soil for a long time. (Ms. NA, in her 40s in Cluster 3) 
The changes in these villages have brought better income, but have caused concern among some villagers.

Earlier, cash income came from cattle. We raised buffaloes and sold them. Now, we have less cash income, especially with the low rubber prices. The price of rubber is too low. It is better to do other things. We earned better when we were raising buffaloes, but we cannot go back to that time. (Ms. $\mathrm{KM}, 80$ years old in Cluster 3 )

Some villages have completely changed their livelihood to rubber. In such cases, the impact of low rubber prices has been severe.

We invested all the money we had on rubber. We hired others and bought machines. Now, rubber is our sole income [so even though the price is low, we cannot quit]. (Ms. CS, 37 years old in Cluster 3)

The family of Ms. SP, in Cluster 3, sacrificed not only their land but also her education for rubber. So, the drop in rubber prices has hit them hard. Her father was a village head and decided to plant rubber. But since he was too busy to attend to it, Ms. SP had to quit school to work with her mother on the trees.

We had more money earlier. We have invested all the money we had on rubber. But now the price of rubber has dropped. (Ms. SP, 23 years old)

Due to the low rubber prices, Chinese companies have not yet come to collect their share of the latex. Once they come, villagers might face a further decrease in income for the same labour. It is not clear whether Cluster 4 villagers will ever be able to benefit as much as villagers in other clusters have done, since they have lost the opportunity to earn during the boom. The over-dependence on rubber is making villagers vulnerable. Rigg et al. (2016) called such a situation, created by the changing market, 'precarious', differentiating it from vulnerability, which was the original condition of the villagers. Both women and men in the 
study villages are in a more precarious condition, and any gains that women made in the transition could get lost under such conditions.

\section{Concluding discussion}

In seven of our eight study villages, respondents were small holder producers who also undertook wage labour in rubber plantations. Variations in individual contract arrangements with rubber companies did not produce large differences among producers with small holdings. In line with Khamphone and Sato (2011), we note that such producers experienced a positive impact, while villagers who were only employed by rubber plantations experienced a negative impact from rubber production. Those who started rubber plantations earlier (Cluster 1 ) benefited from the rubber boom and enjoyed a higher income.

As Agarwal (2003) and Kandiyoti (2003) noted, the household livelihood strategy was gender-specific, with women taking up less lucrative options such as daily wage labour and men taking up rubber, which was more lucrative. The gender differential was because women were primarily responsible for managing food security for the family (Schneider 2011). Such division of labour has led to men doing more farm work than before, although women still put in more more hours of wage work than men.

Following the increase in income, some resources are being used for the benefit of women. While men continue to control the increased incomes, they have allowed women to buy time-saving devices such as refrigerators, and the community has invested in electricity and water supply, which reduce women's workloads. However, such changes were not seen in all communities. Cluster 1 had a higher cash income and saw more women-friendly changes at the household and community level. Cluster 2 villages are far from the market and hence the changes were more gradual, as income came from multiple sources: NTFP collections, wage labour and rubber. Cluster 3 villages are near the market and road, and hence, purchased food from the market. However, since their income was not as high as Cluster 1, not much income was invested in supporting women. Cluster 4 had the least change, 
because they have not yet been able to monetise rubber and are coping with multiple transitions, including recent relocation. Although Cluster 1 experienced the most change for women, this has not been institutionalised through progressive gender norms, and daughters' education is still a lower priority.

The differences can be further analysed by location (distance from border), infrastructure (distance from roads), land arrangements (concession, small farm holding) and timeline. Cluster 1 is near the border with China, and till recently, was considered remote from the provincial centre. Hence, it was far from the reach of the Lao state, but was near the China market. This location allowed villagers to begin rubber plantation much earlier than other farmers in the central lands. When the highway linking China and Laos was constructed, this increased their proximity to the Lao state and their exposure to both China and Laos. This, together with increased income through early adoption of rubber, has influenced gender relations and division of labour. The 'social interface' (Long 2001) at the border worked in favour of women, and exposure to outsiders has led to improved amenities that support women's work.

Cluster 2 was near the Chinese border, and hence, adopted rubber earlier as well. But compared to Cluster 1, these villages were further away from the Chinese market. Access from the provincial centre was also worse than in other clusters. Such isolation has resulted in a certain balance in their livelihood, and changes have been gradual, with rubber being part of a diversified income source rather than the sole income as in other clusters. Status quo has also been maintained in gender roles and relations.

The Cluster 3 villages are in close proximity to the Lao state, with good road access to the Lao market, but far from the border. When the Lao government promoted rubber, the villages adopted it. The changes and increase in income have been more gradual than in Cluster 1 , since the village grew with the Lao market, which is much smaller than the Chinese one. Because of this conservative access to the outside world and a modest income increase, gender roles and relations have not changed much. 
The Cluster 4 village was originally located far from the border as well as from Lao state. However, with relocation, a new livelihood has been imposed on them, with rubber, and they are still trying to adjust. The large transition in their location and their relations with external forces have created a stressful 'social interface' (Long 2001), and while men struggle to find a primary occupation in the relocated area, women are struggling to meet the family's daily needs.

Our study showed the importance of contextual diversities in understanding gendered outcomes (Hall et al. 2017; Arun 2012; Angeles and Hill 2009) and how social interface affects the gender division of labour and relationships. Those at the border between Laos and China were able to take advantage of information from China to adopt rubber plantations when the price was good. The border area gave women greater exposure to outside communities in their pursuit of income-generating opportunities in China, where there was healthy demand for labour from Laos. Those further from the border and even further from the main road did not have as much exposure to outside communities, because of which women were restricted to traditional divisions of labour. These villages were also late in adopting rubber plantations.

In all the villages, except for Cluster 4, which was disadvantaged in terms of location, infrastructure, land arrangement (concession) and timeline (late adopter), rubber plantations were considered a positive change by both women and men. But the involvement of cross-border Chinese investors poses serious questions regarding the sustainability of these positive changes (Kenney-Lazar et al. 2018), a sentiment expressed by some villagers in our study. The transformation of gender relations is not linear, as sociocultural and institutional factors all play a large role in women's lives. While it is difficult to assess the long-term gender impact of current changes, it is important to create an enabling and supportive environment so that women's choices are not born of desperation and lead towards empowerment.

Reference: 
Agarwal, Bina (2003) "Gender and land rights revisited: Exploring new prospects via the state, family and market", Journal of Agrarian Change, 3(1-2): 184-224.

Angeles, Leonora C. \& Kathryn Hill (2009) "The gender dimension of the agrarian transition: women, men and livelihood diversification in two peri-urban farming communities in the Philippines", Gender, Place \& Culture, 16(5): 609-629.

Arun, Shoba (2012) “'We are farmers too': agrarian change and gendered livelihoods in Kerala, South India", Indian Journal of Gender Studies, 21(3): 271-284.

Dwyer, Michael B. (2013) "Building the politics machine: Tools for "resolving" the global land grab", Development and Change, 44(2): 309-333.

Dwyer, Michael B. (2014) “Micro-geopolotics: Capitalising security in Laos's Golden Quadrangle", Geopolitics, 19(2): 377-405.

Elmhirst, Rebecca. (2011) "Migrant pathways to resource access in Lampung's political forest: Gender, citizenship and creative conjugality", Geoforum 42(2): 173-183.

Elmhirst, Rebecca, Mia Siscawati, Bimbika Sijapati Basnett \& Dian Ekowati (2017): Gender and generation in engagements with oil palm in East Kalimantan, Indonesia: insights from feminist political ecology, The Journal of Peasant Studies, (published online).

Evrard, Olivier and Yves Goudineau. (2004) "Planned resettlement, unexpected migrations and cultural trauma in Laos," Development and Change, 35(5): 937-962.

Friis, Cecilie, Anette Reenberg, Andreas Heinimann and Oliver Schonweger (2016) "Changing local land systems: Implications of a Chinese rubber plantation n Nambak District, Lao PDR", Singapore Journal of Tropical Geography, 37(1): 25-42.

Hall, Ruth, Ian Scoones \& Dzodzi Tsikata (2017) Plantations, outgrowers and commercial farming in Africa: agricultural commercialisation and implications for agrarian change, The Journal of Peasant Studies, 44(3): 515-537.

Horstmann, Alexander and Reed L. Wadley (eds) (2006) Centering the margin: agency and narrative in Southeast Asian borderlands, New York: Berghahn Books.

Julia, with Ben White (2013) "Gendered experiences of dispossession: oil palm expansion in Dayak Hibun community in West Kalimantan" in Ben White, Saturnino M. Borras Jr., Ruth Hall, lan Scoones and Wendy Wolford (eds.) The New Enclosures: Critical Perspectives on Corporate Land Deals, 377-398, New York:Routledge.

Kandiyoti, Deniz (2003) "The cry for land: Agrarian reform, gender and land rights in Uzbekistan", Journal of Agrarian Change, 3(1-2): 225-256. 
Kenney-Lazar, Miles, Grace Wong, Himlal Baral, and Aaron J.M. Russell (2018) "Greening rubber? Political ecologies of plantation sustainability in Laos and Myanmar", Geoforum, 92, 96-105.

Khamphone, Bounthavy and Noriko Sato (2011) "Effectiveness of rubber plantation on villagers' livelihood improvement in the Northern part of Laos", Journal of Faculty of Agriculture, Kyushu University, 56(1): 185-191.

Kusakabe, Kyoko and SengkhamVongphakdy (2014) "Gender vulnerabilities of resettlement and restricted mobility of ethnic groups in northern Laos", in Ragnhild Lund, Kyoko Kusakabe, Smita Mishra Panda and Yunxian Wang (eds) Gender, mobilities, and livelihood transformations: Comparing indigenous people in China, India, and Laos, 134-165, Routledge, London.

Kusakabe, Kyoko, Ragnhild Lund, Smita M. Panda, Wang Yunxian (2015) "Resettlement in Lao PDR: Motility, resistance and gendered impacts", Gender, Place and Culture, 22(8): 1089-1105.

Lagerqvist, Yayoi Fujita (2013) "Imagining the borderlands: Contending stories of a resource frontier in Muang Sing”, Singapore Journal of Tropical Geography, 34(1): 57-69.

Lindeborg, Anna-Klara (2012) "Where Gendered Spaces Bend: The Rubber Phenomenon in Northern Laos", Ph.D dissertation, Kulturgeografiska institutionen. Geografiska regionstudier 89. $261 \mathrm{pp}$. Uppsala.

Long, Norman (2001) Development sociology: actor perspectives, London: Routledge.

Lu, Juliet (2015) "Tapping into the rubber market: opium replacement and the role of rubber in developing Laos", Land grabbing, conflict and agrarian-environmental tranformations: perspectives from East and Southeast Asia, Conference paper No. 13, Chiangmai University, June.

Lyttleton, Chris, Houmphanh Rattanavong, Paul Cohen, Bouakham Tongkhamhane, Souriyanh Sisaengrat (2004) Watermelons, bars and trucks: dangerous intersections in Northwest Lao PDR, Institute for cultural research of Laos and Macquarie University.

McAllister, Karen E. (2015) Rubber, rights and resistance: the evolution of local struggles against a Chinese rubber concession in Northern Laos, The Journal of Peasant Studies, 42(34): 817-837.

Nightingale, Andrea. (2011) "Bounding difference: Intersectionality and the material production of gender, caste, class and environment in Nepal”, Geoforum, 42(2): 153-162.

Park, Clara Mi Young and Elizabeth Daley (2015) "Gender, and and agricultural investments in Lao PDR" in Caroline S. Archambault and Annelies Zoomers (eds) Global trends in land tenure reform: Gender impacts, 17-34, London: Routledge. 
Rigg, Jonathan, Katie J. Oven, Gopi Krishna Basyal, Richa Lamichhane. (2016). "Between a rock and a hard place: Vulnerability and precarity in rural Nepal," Geoforum, 76, 63-74.

Schenk-Sandbergen, Loes (2012) "The Lao matri-system, empowerment and globalisation", Journal of Lao Studies, 3:1, 65-90.

Schneider, Alison Elizabeth (2011) "What shall we do without our land? Land grabs and resistance in rural Cambodia", paper presented at the international conference on Global land grabbing, 6-8 April, University of Sussex.

Shi, Weiyi. (2008) "Rubber boom in Luang Namtha: A transnational perspective," TGZ, Vientiane.

Sturgeon, Janet C. (2005) Border landscapes: The politics of Akha land use in China and Thailand, Seattle: University of Washington Press.

Sturgeon, Janet C. (2012) "Cross-border rubber cultivation between China and Laos: Regionalizatoin by Akha and Tai rubber farmers", Singapore Journal of Tropical Geography, 34(1): 70-85.

Sturgeon, J.C., N.D. Menzies, Y. F. Lagerqvist, D. Thomas, B. Ekasingh, L. Lebel, K. Phanvilay, S. Thongmanivong (2013) "Enclosing ethnic minorities and forests in the golden economic quandrangle", Development and change, 44:1, 53-79.

Sultana, Farhana (2009) "Community and participation in water resources management: gendering and naturing development debates from Bangladesh", Transactions of the institute of British geographers, 34(3): 346-363

Terry, Geraldine (2011) Climate, change and insecurity: Views from Gisu hillside, Doctoral thesis, University of East Anglia.

Thongmanivong, Sithong, Fujita Yayoi, Khamla Phanvilay, Thoumthone Vongvisouk (2009) "Agrarian land use transformation in Northern Laos: From swidden to rubber", Southeast Asian Studies, 47(3): 330-347.

Turner, Sarah, Christine Bonnin, Jean Michaud (2015) Frontier livelihoods: Hmong in the Sino-Vietnamese borderlands, London: University of Washington Press.

Whitehead, Ann and Naila Kabeer (2001) "Living with uncertainty: gender, livelihood and pro-poor growth in rural sub-Saharan Africa", IDS working paper 134, Institute of Development Studies, Sussex.

World Bank (2017) Lao poverty policy brief: Why are ethnic minorities poor?, World Bank Group, Vientiane. 
Table 1: $\quad$ Profile of respondents by cluster

\begin{tabular}{|c|c|c|c|c|c|}
\hline & $\begin{array}{l}\text { Cluster } \\
1\end{array}$ & $\begin{array}{l}\text { Cluster } \\
2\end{array}$ & $\begin{array}{l}\text { Cluster } \\
3\end{array}$ & $\begin{array}{l}\text { Cluster } \\
4\end{array}$ & Total \\
\hline Average start to planting rubber (year) & 2004.5 & 2006.3 & 2006.4 & 2009.9 & 2006.4 \\
\hline \multicolumn{6}{|l|}{ Main person working on rubber (\%) } \\
\hline \begin{tabular}{l|l} 
Men \\
\end{tabular} & 29.3 & 40.0 & 44.3 & 18.5 & 34.3 \\
\hline Women & 19.2 & 20.0 & 22.7 & 70.4 & 29.2 \\
\hline \begin{tabular}{l|l} 
& Both equally \\
\end{tabular} & 51.5 & 40.0 & 33.0 & 11.1 & 36.5 \\
\hline \multicolumn{6}{|l|}{$\begin{array}{l}\text { Main person working on upland rice } \\
(\%)\end{array}$} \\
\hline \begin{tabular}{l|l} 
Men \\
\end{tabular} & 12.2 & 9.5 & 9.8 & 9.4 & 10.2 \\
\hline Women & 37.8 & 36.5 & 70.7 & 78.1 & 56.2 \\
\hline Both equally & 50.0 & 54.0 & 19.5 & 12.5 & 33.6 \\
\hline \multicolumn{6}{|l|}{ Busier after adoption of rubber (\%) } \\
\hline \begin{tabular}{l|l} 
Men \\
\end{tabular} & 54.2 & 68.8 & 77.9 & 88.5 & 73.8 \\
\hline \begin{tabular}{l|l} 
Women \\
\end{tabular} & 33.9 & 51.9 & 95.9 & 100 & 62.0 \\
\hline $\begin{array}{l}\text { Increased investment in son's } \\
\text { education (\%) }\end{array}$ & 76.9 & 58.7 & 65.8 & 62.1 & 66.9 \\
\hline $\begin{array}{l}\text { Increased investment in daughter's } \\
\text { education (\%) }\end{array}$ & 60.6 & 56.0 & 65.0 & 25.8 & 54.7 \\
\hline \multicolumn{6}{|l|}{ Total number of respondents } \\
\hline \begin{tabular}{l|l} 
Men \\
\end{tabular} & 48 & 48 & 68 & 61 & 225 \\
\hline Women & 56 & 27 & 49 & 5 & 137 \\
\hline Total & 104 & 75 & 117 & 66 & 362 \\
\hline
\end{tabular}

Source: Questionnaire survey

\section{Note on informed consent:}

All respondents were informed of the research and asked for their consent to participate in the interview. 